\author{
D.N. Ulybyshev ${ }^{1,2,3}$, Ye.S. Petrenko ${ }^{1,2}$, Ye.B. Zhailauov ${ }^{1,3, *}$, N.D. Kenzhebekov ${ }^{1,3}$, A.K. Kabdybay ${ }^{1,4}$ \\ ${ }^{1}$ RATIONAL SOLUTION LLP, Kazakhstan \\ ${ }^{2}$ Plekhanov Russian Economic University, Russian Federation \\ ${ }^{3}$ Karaganda Economic University of Kazpotrebsoyuz, Kazakhstan \\ ${ }^{4}$ Buketov Karaganda State University, Kazakhstan

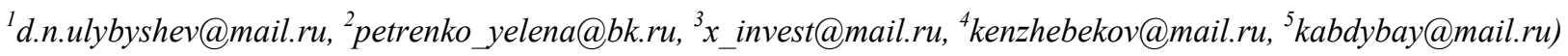

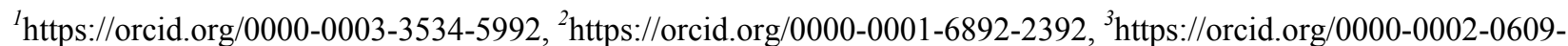 \\ 6256, ${ }^{4}$ https://orcid.org/0000-0002-1292-8653, ${ }^{5}$ https://orcid.org/0000-0002-3149-9727 \\ ${ }^{1}$ Scopus Author ID: 57201644794, ${ }^{2}$ Scopus Author ID: 57192267828, ${ }^{3}$ Scopus Author ID: 57194586056, \\ ${ }^{1}$ Researcher ID: AAA-8631-2019, ${ }^{3}$ Researcher ID: AAM-7238-2020, ${ }^{5}$ Researcher ID: AAF-6871-2020
}

\title{
Factors of enterprises' innovative susceptibility
}

\begin{abstract}
Object: To explore the conceptual basis for determining the innovative susceptibility of economic actors and their influence factors.

Methods: The methodological basis of the study was evolutionary theory of economic growth, concepts of innovation process and innovative susceptibility. Methods of systematic and institutional analysis of processes of perception of innovation in national and regional innovation systems were used.

Results: Exogenous (type of economic system, openness of economy, place in the international division of labor) and endogenous (competition, institutions, innovative potential) factors of innovative development have been identified.

Exogenous factors do not depend directly on the activities of the firm, and often overall state, but the dynamics of these factors should be taken into account in the process of implementation of both innovation policies of the state and innovation projects of the firms. More important for entrepreneurs are endogenous factors. At the same time, it is necessary to take into account that the main part of potential innovative shifts is created in the sphere of generation of new knowledge, where human activity is determined not by technological logic of production, but by laws and incentives of creative process. In this regard, the fundamental feature of internal factors of innovative development is that a new variable is introduced - intellectual capital, characterizing the volume of accumulated scientific knowledge and practical experience.

A detailed assessment of innovation susceptibility factors allows them to be classified by place of origin within the existing innovation process: environmental factors, business factors, legal regulatory factors, social factors and science factors.

Conclusions: Identification of factors of innovative susceptibility of economic relations subjects allows defining parameters of innovative interaction of innovative companies with external and internal elements of innovation process.

Keywords: innovation susceptibility, innovations, national innovation system, innovation activity, innovation environment, external and internal factors of innovation development, innovation potential, innovation process.
\end{abstract}

\section{Introduction}

The innovation process in Kazakhstan has many gaps that do not allow effective innovation activities, and the national innovation system does not yet have all the necessary mechanisms to increase innovation activity. So, for today the experience of science and innovation development cannot be recognized as fully successful. An important study in this regard is not only and not so much the innovation process itself and the impact and impact of innovation, as the ability of economic agents to perceive innovation and incorporate it into their business practices. In addition, for any state is to contribute to this process through all available methods of public regulation and management, because innovative susceptibility in this context is a property resulting from all previous business activities and determining future competitiveness or exit from the market.

Consequently, it can be recognized that the study of problems of innovative susceptibility is relevant for the development of economic science and economic practice of Kazakhstan.

It is expected that the identification of factors of innovative susceptibility of economic relations actors will allow building a system of evaluation of parameters of innovative interaction. Based on the parameters

\footnotetext{
* Corresponding author.

E-mail address: x_invest@mail.ru
} 
of innovative interaction, the types of interaction of innovative companies with external and internal elements of the innovation process will be determined.

Thus, the main scientific issue of this study is the definition of the role of a number of factors in the formation of innovative susceptibility of firms and the economy as a whole.

\section{Literature Review}

The synthesis of the results of research on innovative susceptibility of subjects has highlighted two main approaches: systemic and subject. Several authors consider innovative susceptibility from the point of view of the system, revealing it from the point of view of the property of the system, the property of the subject, the ability to use innovation. At the same time, authors who assessed innovative susceptibility in one way or another assigned to innovative susceptibility the function of a basic indicator determining the ability of the system or subject to introduce innovation (Shatrevich, Strautmane, 2015, Amoroso, Audretsch, Link, 2018, Vieira, 2017).

Other authors reveal innovative susceptibility from a perspective not of a systemic approach, but of a subject approach (Aguiar, Gagnepain, 2017, Elnasri, Fox, 2017). For example, the work (Vladimirova, 2011) defines "The innovative sensitivity of a region is the presence and ability of regional actors and executive authorities to create, implement and implement innovative processes based on existing conditions and resources, within a defined and ongoing regional innovation policy."

In our view, more attention should be paid not so much to innovative susceptibility as a feature of a system or object, but to the perception of innovation as an economic process, in order to ultimately determine what is perception and what is susceptibility, and how these concepts relate in modern economic practice.

Systematizing the works of domestic and foreign scientists, the following significant characteristics of innovative susceptibility should be highlighted:

1) economic category to be considered within a single industry or market, or, in other words, the ability of business units to perceive innovations and introduce them into their operations;

2) multi-vector, i.e. the ability to innovate in different sectors of the economy, in different spheres of activity within the firm;

3) process of considering innovation, recommendations for its adoption and implementation based on the resources of the firm;

4) property dynamically varying according to the stages of the life cycle of innovation (stages of growth, maturity, and decline, which qualitatively determine the phase state of the firm).

This approach to innovative susceptibility explains to us why this property of subjects and systems is complex and diverse, and not totally measurable from the perspective of a specific quantification of perception.

The description of the concept of innovation sensitivity and key elements and participants in the process of perception of innovation should be logically supplemented by a description of the factors that mediate innovation activities of economic entities and have a direct impact on all stages of the innovation process. For better understanding the actions of each of the factors, consider them relative to both the macroeconomic system and the level of the innovation firm.

The effective functioning of innovative firms and, consequently, the socio-economic system is influenced by several external (exogenous) and internal (endogenous) factors of innovative development (Tambovtsev, 2018).

\section{Methods}

The subject of the study is a set of organizational and economic relations arising in the process of perception of innovation in socio-economic systems.

The methodological basis of the study was evolutionary theory of economic growth, concepts of innovation process and innovative susceptibility. Methods of systematic and institutional analysis of processes of perception of innovation in national and regional innovation systems were used.

\section{Results}

Exogenous and endogenous factors of innovative development were summarized (Figure 1).

Exogenous factors (the type of economic system, the degree of openness of the economic system of the state and the place of the socio-economic system of the country (region) in the international division of labor) are practically not regulated and form the general conditions of operation of the innovation firm in the 
form of the possibility to freely engage in innovation activities, freely trade goods, services, patents, technologies, etc., with foreign and local partners, as well as participate in international cooperation.

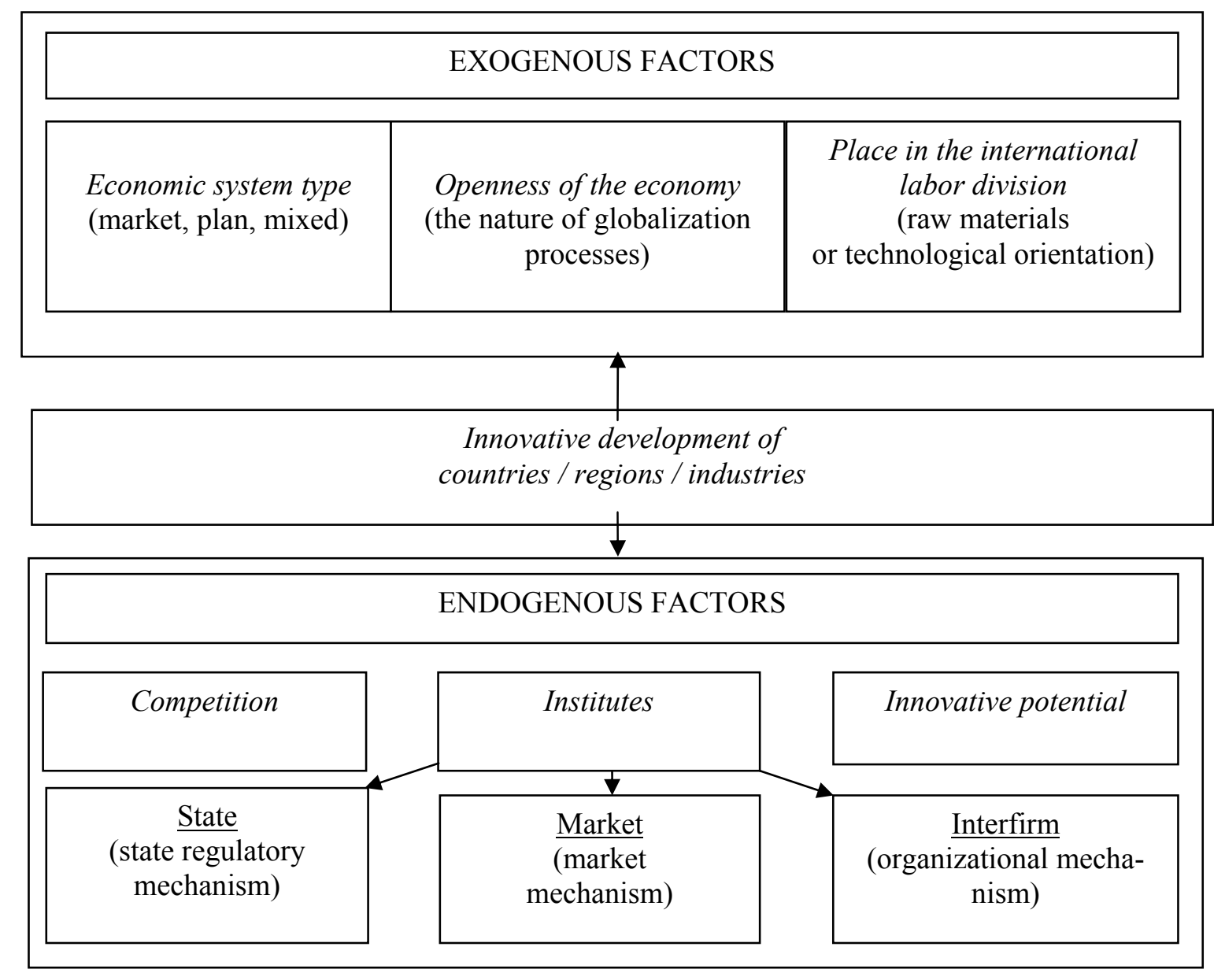

Figure 1. Factors of innovative development of the socio-economic system

Note - compiled by authors based on (Salimyanova, 2011)

At the same time, it should be understood that although these factors do not depend directly on the activities of the firm, and often on the whole State, the dynamics of these factors should be taken into account in the process of implementation of both innovation policies of the State and innovation projects of the firms. The perception of innovation is in one way or another based on the consideration of these factors, and their change can fundamentally change the perception of a particular innovation.

More important for entrepreneurs are endogenous factors. Consider the first endogenous factor - competition. The modern stage of competition, which links the competitive advantages of enterprises with the availability and possession of a developed innovative base, shifts the emphasis of competition of producers from the product and resource level to the level of effective promotion of innovative goods through the application of new technological and organizational-economic solutions. Ultimately, the competitiveness of industry, the region or the country as a whole depends on the ability of a particular producer to produce a competitive commodity.

The second endogenous factor is institutions. Competition, as an important factor and mechanism for innovative development of the economic system, stimulates processes of institution-building, which allow to overcome "market failures" by reducing transaction costs. However, the existence of institutions can also have a negative impact on the competitive environment of the market, which may lead to "monopoly failures," public sector failures "and other negative effects.

The third exogenous factor of innovation development is innovation potential, which should be understood not only as a set of resources that create new knowledge for innovation, but also as an organizational mechanism necessary to achieve the goal in the field of knowledge-intensive and technological processes 
and products. At the same time, it is necessary to take into account that the main part of potential innovative shifts is created in the sphere of generation of new knowledge, where human activity is determined not by technological logic of production, but by laws and incentives of creative process. In this regard, the fundamental feature of internal factors of innovative development is that a new variable is introduced - intellectual capital, characterizing the volume of accumulated scientific knowledge and practical experience.

If we explore in more detail the factors that influence the perception of innovation, you can classify them by site as part of an existing innovation process. Based on this classification, 5 groups of factors are identified:

1. Environmental factors that include four factors:

- low production variety;

- lack of interest of the large local companies;

- weak support of small and medium business by administration;

- inconsistency of economic development.

This group of factors is generally responsible for the fact that the implementation of any innovative project in the field involves difficulties in finding the required resources, materials, equipment, personnel. When assessing the innovation component of the project, it is always necessary to take into account that the partner for the implementation of the project with a high probability will have to be sought outside the project region; Local administrations have very few resources to allocate to the innovation process. And the constant change of socio-economic policy vectors makes it unsustainable for a potential innovative business to lack firm guarantees of the stability of legislation for a certain period of time (Ulybyshev D.N. et al., 2017).

2. Business factors that include three factors:

- low market demand of innovations;

- low probability of commercial success of an innovation at considerable risks;

- lack of effective coordination of the innovative ideas.

Within this group of factors, there is a clear reference to the risk nature of entrepreneurship in general and innovative entrepreneurship in particular. In addition to this, Kazakhstan is a country with very low economic density and low aggregate domestic demand, which in many cases is easier to satisfy without organizing production within the country, but by importing products from abroad. It is also worth noting the low connectivity of the economic space and the poor organization of network structures in which it would be possible to organize innovative business, but at the current level of support and coordination, it is not possible to include it in the established structure of economic relations (Kurmanov, N.A., Aibosynova, D.A., 2016).

3. Regulatory factors, which include three factors:

- inconsistency in innovative and technical policy;

- lack of the accurate concept of development;

- weakness of the innovative legislation.

This group of factors is responsible for the fact that in domestic practice there is no normal legal field of regulation of innovative processes both in terms of frequent change of guidelines in innovation policy of the state, and in terms of absence of a cross-cutting unified approach to formation of state decisions on innovation business. The weakness of scientific and innovative legislation is manifested in the lack of work of such important issues as the use of intellectual property, its assessment, the organization of innovative enterprises (with special status and special regime of operation), clear regulation of financing of scientific research, etc. (Mukhtarova K. et al., 2017).

4. Social factors that include two factors:

- low standard of living of the population;

- low solvent demand for innovations.

The low standard of living of the population primarily affects the consumer preferences of the population, as the degree of competitiveness of goods is determined not by their high consumer qualities. But by their low price, and, as a result, entrepreneurs should pay more attention not to the introduction of food innovations in order to expand the range of goods, but to the constant introduction of processed goods, which are intended to reduce cost. Logically, it follows that consumers are not focused on finding new goods, but on consuming traditional, low-cost and low-price products (Marcotte C., 2014).

5. Science factors that include 4 factors:

- civilization gap; 
- weak support of the international cooperation;

- insufficient investment literacy;

- lack of the innovative centers.

\section{Discussions}

First, Kazakhstan and its economically developed partners are at various stages of technical and technological development and what is new for the domestic science and innovation sphere, in the far abroad already belongs to traditional goods and services. If Kazakhstan is able to increase the resources of science and innovative business, there is still a lack of institutional flexibility and extreme rigidity of the legislation. The second factor largely influences through the formation of systems to recognize academic achievement and the exchange of scientific and innovative achievement. Domestic scientists and innovators-entrepreneurs are poorly involved in international academic exchange and often have no idea of what is happening abroad. Insufficient investment literacy prevents domestic researchers from moving freely from the category of scientists to the category of entrepreneurs, which negatively affects the dynamics of the development of the small innovative enterprises sector. Finally, the absence of innovative centers is a big problem of fading and lack of support to traditional scientific and industrial regions (Almaty, Karaganda and East Kazakhstan regions), where high scientific potential is concentrated, which due to lack of resources and economic ties remains unclaimed.

Thus, it can be noted that at the macro- and meso-levels of economic relations there is a set of factors both contributing to and impeding the innovation process in general and the process of perception of innovation in particular.

Let us look at the factors that affect the perception of innovation at the micro level.

The firm's innovative susceptibility is mediated by the following conditions:

1) technological specificity (degree of process integration and possibility of its improvement);

2) market capacity and product prospects,

3) financial position of the enterprise,

4) technological capabilities of the enterprise (availability of technological base for innovation);

5) company's market strategy,

6) subjective factors (entrepreneurship and flexibility of management, ability to rationalize the use of available resources, including intellectual resources, and their progressive increment),

7) enterprise life cycle stage (Taubayev, Kamenova, 2019).

The level of innovative susceptibility of the firm at the same time reflects its ability to perceive innovative tasks, as well as introduction and use of innovations of various kinds in its activities. Innovative susceptibility is positive when the production system is interested and prepared to introduce innovations, negative when innovation is contrary to the interests of the enterprise, or when the production system is not ready to implement them, and the control subsystem lacks effective leverage.

Accordingly, the basic factors of innovative susceptibility of firms will then be:

- Level of information support for making management decisions on attracting or developing innovations;

- Level of methodological support for making management decisions on attracting or developing innovations;

- Level of organizational support for making and implementing management decisions on attracting or developing innovations;

- Level of financial support for implementation of measures to attract, develop or implement innovations.

Some authors point out that in addition to system-wide factors, which are based on general problems and shortcomings of existing economic mechanisms, resource constraints, difficulties in finding information and suitable facilities for the formation and implementation of innovative projects, innovation susceptibility is strongly influenced by factors that depend largely only on the entrepreneur himself. Among such factors, we have identified the system of innovative organizational culture and mechanisms of economic interaction (Tambovtsev, 2018).

Therefore, the system of innovative organizational culture implies the consistent construction of three interrelated subsystems: functional, elementary (resource) and organizational (structural). 
The functional subsystem determines the main functions of the system of innovative organizational culture and the composition of task functions, as well as the construction of the function tree.

The element subsystem provides for allocation of elements necessary for implementation of functionstasks in the system, as well as corresponding element (resource) support.

The organizational subsystem provides for the creation of the structure of the management system for the formation of an innovative organizational culture and the development of a mechanism for the implementation of its functions, as well as the establishment of links and relations between the elements.

The model of the system of innovative organizational culture according to the system approach is given in Table 1.

Table 1. Innovative organizational culture system

\begin{tabular}{|l|l|l|}
\hline Functional subsystem & Element subsystem & Organizational subsystem \\
\hline 1. Formation of labor culture & 1. Executors & 1. Structure responsible for \\
2. Formation of production culture & 2. Legal resources & the development of organ- \\
3. Provision of conditions for research work & 3. Information resources & izational culture \\
$\begin{array}{l}\text { 4. Providing conditions for professional development } \\
\text { 5. Ensuring the creative development of employees }\end{array}$ & $\begin{array}{l}\text { 4. Financial resources } \\
\text { 5. Technical resources } \\
\text { 6. Control of use of resources }\end{array}$ & $\begin{array}{l}\text { 2. Structure implementing } \\
\text { principles of correct moti- } \\
\text { vation of personnel }\end{array}$ \\
\hline \multicolumn{2}{|l|}{ Note - compiled by author on the basis (Shevchenko, Goncharuk, 2018) } \\
\hline
\end{tabular}

The formation of a specific innovative organizational culture of the firm enables the development of the business unit at a faster pace, as the staff of the firm will be interested in preserving and increasing the benefits they enjoy or receive from the firm. At the same time, the severity of the control function is reduced, as the company has an opportunity for the creative component of work, motivational mechanisms are changed, best management practices are used.

Evaluation of the main forms of interaction as a factor of innovative susceptibility of enterprises a set of forms of interaction and parameters of interaction is drawn up, the list of the main ones is presented in Table 2 .

Table 2. System for evaluation of innovative interaction parameters

\begin{tabular}{|l|l|}
\hline Interaction form & Ключевой фактор взаимодействия \\
\hline $\begin{array}{l}\text { Internal interaction of enterprise functional sub- } \\
\text { systems }\end{array}$ & $\begin{array}{l}\text { Enterprise-controlled intangible assets } \\
\text { Managerial Skills }\end{array}$ \\
\hline $\begin{array}{l}\text { External competitive interaction of the enterprise } \\
\text { with agents of the near-market environment }\end{array}$ & $\begin{array}{l}\text { Competitive enterprise interaction with single industry manu- } \\
\text { facturers }\end{array}$ \\
\hline $\begin{array}{l}\text { External cooperation of the enterprise with agents } \\
\text { of the near-market environment }\end{array}$ & $\begin{array}{l}\text { Joint R\&D with other enterprises } \\
\text { Enterprise's use of innovative infrastructure organizations }\end{array}$ \\
\hline \multirow{3}{*}{$\begin{array}{l}\text { Direct external interaction of the enterprise with } \\
\text { the company }\end{array}$} & $\begin{array}{l}\text { Direct budget payments for enterprise development } \\
\text { Payments for enterprise development from extrabudgetary funds } \\
\end{array}$ \\
& $\begin{array}{l}\text { Development tax preferences granted to the enterprise } \\
\text { Purchase of new products of the enterprise within the frame- } \\
\text { work of the system of state order for innovative development }\end{array}$ \\
\hline \multicolumn{2}{|l|}{ Note - compiled by the author on the basis (Komkov, 2004, Ulybyshev, Kenzhebekov, 2017) } \\
\hline
\end{tabular}

\section{Conclusions}

At the end of the review of factors influencing the process of perception of innovation, we identify the following innovative subsystems: individual, firm (enterprise) and national economy. At the level of "individual," a person is considered, he is the reason for all the changes taking place. On the one hand, he is the creator of innovation, and on the other - their consumer. In order to accomplish both, it must possess sufficient human capital. Thus, the need to increase the resilience of the individual in the labor market and his or her ability to develop innovative products encourages the latter to accumulate human capital, embodied in knowledge, skills and production experience. The use of those will allow the individual to persistently establish himself or herself in a particular segment of the labor market and to ensure positive dynamics of personal income.

At the micro level, the "firm" is seen as an enterprise as a whole, the potential of the staff and the products produced or the service rendered. It can achieve competitive advantage, success in the market by producing innovative products or services that will be preferred by consumers. For this purpose it needs to improve constantly quality or to create essentially new products due to use of the innovative potential. In this 
regard, the enterprise needs to have a high innovative potential of personnel, which can be formed due to accumulated human capital.

In total, the firm can build four types of interactions oriented to the internal and external environment:

- internal interaction of functional subsystems of the enterprise

- external competitive interaction of the enterprise with agents of the environment of the immediate market environment

- external cooperation interaction of the enterprise with agents of the environment of the immediate market environment

- direct external interaction of the enterprise with society

These forms of interaction correspond to 9 factors that have a direct impact not only on the effectiveness of the company's interaction with its partners and counterparties, but also show (within the framework of its dynamics) which form of interaction brings the greatest effect in the context of innovative susceptibility, and which forms require correction or elimination from the relationship system. It is also necessary to understand here that the current relationship model is highly subject to temporal changes, as the interaction system can change under the influence of external factors. And, therefore, one of the most important tasks of an innovative entrepreneur is to achieve relative stability of such a system of relations.

At the macro level, the "national economy" is seen by the national economy as a set of all industries interconnected in the single national economic complex of the country. Its innovative development largely determines the dynamics of national income (GDP) and the high place in the system of inter-country comparisons. This cannot be achieved without the high level of innovative susceptibility of the national economy. It contributes not only to economic growth, but also to its new quality, manifested in both the creation and mastery of high technologies corresponding to the V and VI technological patterns, and in the increase of the share of innovative goods in the total production of both the means of production and the objects of consumption.

\section{Complementary data}

This article was prepared as part of the grant of the Committee of Science of the Ministry of Education and Science of the Republic of Kazakhstan AP05134987 "Innovative susceptibility of EAEU countries' national economies: system characteristics, assessment, mechanisms of management".

\section{References}

Aguiar, L., \& Gagnepain, P. (2017). European cooperative R\&D and firm performance: Evidence based on funding differences in key actions. International Journal of Industrial Organization, 53, 1-31. Doi: 10.1016/j.jijindorg.2016.12.007.

Amoroso, S., Audretsch, D.B., \& Link, A.N. (2018). Sources of knowledge used by entrepreneurial firms in the European high-tech sector. Eurasian Business Review, 8 (1), 55-70. Doi: 10.1007/s40821-017-0078-4.

Elnasri, A., \& Fox, K.J. (2017). The contribution of research and innovation to productivity. Journal of Productivity Analysis, 47 (3), 291-308. Doi: 10.1007/s11123-017-0503-9.

Komkov, S.Yu. (2004). Mekhanizmy ekonomicheskoho vzaimodeistviia kak faktor innovatsionnoi vospriimchivosti predpriiatii [Prerequisites and methodological features of evaluation of innovative susceptibility of production systems]. Vestnik Homelskoho hosudarstvennoho tekhnicheskoho universiteta imeni P.O. Sukhoho [Journal of Sukhoi Gomel State Technical University], 3, 101-110 [in Russian].

Kurmanov, N.A., \& Aibosynova, D.A. (2016). Innovative activity of small and medium enterprises in Kazakhstan and their success factors. Herald of «Turan» University, 72(4), 188-192.

Marcotte, C. (2014). Entrepreneurship and innovation in emerging economies. International Journal of Entrepreneurial Behavior \& Research, 20 (1), 42-65. Doi: 10.1108/IJEBR-09-2012-0089.

Mukhtarova, K., Ziyadin, S., Kupeshova, S., \& Doszhan, R. (2017). Problems of developing the foundations of sustainable competitiveness of industrial and innovative economy in Kazakhstan. Economic Annals-XXI, 168 (11-12), 3843. Doi: 10.21003/ea.V168-08.

Salimyanova I.G. (2011). Metodolohicheskie aspekty postroeniia natsionalnoi innovatsionnoi sistemy [Methodological aspects of the national innovation system]. Saint Petersburg: SPbGIEU [in Russian].

Shatrevich, V., \& Strautmane, V. (2015). Industrialisation factors in post-industrial society. Entrepreneurship and Sustainability Issues, 3(2), 157-172. Doi: 10.9770/jesi.2015.3.2(4).

Shevchenko, M.N., \& Goncharuk, Ye.S. (2018). Otsenka innovatsionnoi vospriimchivosti kak faktor formirovaniia stratehii innovatsionnoho razvitiia ahrarnykh predpriiatii [Evaluation of innovative susceptibility as a factor of formation of innovative development strategy of agricultural enterprises]. EKONOMINFO [EKONOMINFO], 2, 52-62 [in Russian]. 
Tambovtsev, V.L. (2018). On scientific validity of Russian science policy. Questions of Economy, 70, 5-32. Doi: 10.32609/0042-8736-2018-2-5-32.

Taubayev A.A., Kamenova A.B., Borisova E.I., \& Saifullina Yu.M. (2019). Formation in Kazakhstan institutional environment for the development of high-tech sector and innovative entrepreneurship. Corporate Governance and Innovative Economic Development of the North. Bulletin of the Research Center of Corporate Law, Management and Venture Capital of Syktyvkar State University, 1, 104-111. Doi: 10.34130/2070-4992-2019-1-104-111.

Ulybyshev, D.N., \& Kenzhebekov, N.D. (2017). Vozmozhnosti i mekhanizmy razvitiia kazakhstanskoho innovatsionnoho biznesa $\mathrm{v}$ ramkakh Evraziiskoho ekonomicheskoho soiuza [Opportunities and mechanisms for development of Kazakhstan innovation business within the framework of the Eurasian Economic Union]. Yekonomika Tsentralnoi Azii [Central Asia Economy], 1 (3), 145-154. DOI: 10.18334/asia.1.3.38490 [in Russian].

Ulybyshev, D.N., Petrenko, Ye., Lenkova, O., \& Akenov, S. (2017). Priority Directions of Cooperation and Interaction of the Countries of the Eurasian Economic Union in the Scientific and Innovative Environment. Journal of Advanced Research in Law and Economics, 8 (6(28)), 2024-2030. Doi: 10.14505/jarle.v8.6(28).40.

Vieira, A. (2017). A Tale of Two Unions: Russia-Belarus Integration Experience and its Lessons for the Eurasian Economic Union. Journal of Borderlands Studies, 32 (1), 41-53. Doi: 10.1080/08865655.2016.1211959.

Vladimirova, O.N. (2011). Upravleniie innovatsionnoi vospriimchivostiu rehiona: metodolohiia i instrumentarii [Regional Innovation Sensitivity Management: Methodology and Tools]. PhD Thesis. Krasnoyarsk: SHAU [in Russian].

\title{
Д.Н. Улыбышев, Е.С. Петренко, Е.Б. Жайлауов, Н.Д. Кенжебеков, А.Қ. Қабдыбай Кәсіпорындардың инновацияны қабылдау қабілеттілігінің факторлары
}

\begin{abstract}
Аңдатпа
Maķсаты: Экономикалық субъектілердің инновацияны қабылдау қабілеттіліктерінің және оған әсер ету факторларын анықтаудың тұжырымдамалық негіздерін зерттеу.

Әдісі: Зерттеудің әдіснамалық базасы ретінде экономикалық өсудің эволюциялық теориясы, инновациялық процесс және инновацияны қабылдау қабілеттілік тұжырымдамасы пайдаланылған. Ұлттық және өңірлік инновациялық жүйелерде инновацияларды қабылдау үдерістерін жүйелік және институционалдық талдау әдістері қолданылған.
\end{abstract}

Қорытынды: Инновациялық дамудың экзогенді (экономикалық жүйенің түрі, экономиканың ашықтығы және халықаралық еңбек бөлінісіндегі орны) және эндогенді (бәсекелестік, институттар, инновациялық әлеует) факторлары анықталды.

Экзогендік факторлар фирманың қызметіне және көбінесе мемлекеттің қызметіне тікелей байланысты емес, соған қарамастан, осы факторлардың динамикасы мемлекеттің инновациялық саясатын және фирмалардың инновациялық жобаларын іске асыру процесінде ескерілуі тиіс. Кәсіпкерлер үшін эндогендік факторлар аса маңызды болып табылады. Бұл ретте, әлеуетті инновациялық өзгерістердің негізгі бөлігі жаңа білімді генерациялау саласында құрылатынын ескеру қажет, онда адам қызметі өндірістің технологиялық логикасымен емес, заңдармен және шығармашылық процестің ынталарымен айқындалады. Осыған байланысты инновациялық дамудың ішкі факторларының принциптік ерекшелігі - жинақталған ғылыми білім мен практикалық тәжірибе көлемін сипаттайтын жаңа «зияткерлік капитал» атты ауыспалы енгізілуде.

Инновацияны қабылдау қабілеттілігі факторларын егжей-тегжейлі бағалау оларды қазіргі инновациялық процесс шеңберінде пайда болған орны бойынша жіктеуге мүмкіндік береді: қоршаған факторлар, бизнесфакторлар, құқықтық реттеу факторлары, әлеуметтік факторлар және ғылым факторлары.

Тұжырымдама: Экономикалық қатынастар субъектілерінің инновациялық қабылдаушылық факторларын анықтау инновациялық компаниялардың инновациялық процестің сыртқы және ішкі элементтерімен инновациялық өзара іс-қимыл параметрлерін анықтауға мүмкіндік береді.

Kiлm сөздер: инновацияны қабылдау қабілеттілігі, инновация, ұлттық инновациялық жүйе, инновациялық белсенділік, инновациялық орта, инновациялық дамудың сыртқы және ішкі факторлары, инновациялық әлеует, инновациялық процесс.

\section{Д.Н. Улыбышев, Е.С. Петренко, Е.Б. Жайлауов, Н.Д. Кенжебеков, А.К. Кабдыбай Факторы инновационной восприимчивости предприятий}

\section{Аннотация}

Цель: Исследовать концептуальные основы определения инновационной восприимчивости экономических субъектов и факторов воздействия на него.

Memoдbl: Методологической базой исследования выступили эволюционная теория экономического роста, концепции инновационного процесса и инновационной восприимчивости. Были использованы методы системного и институционального анализа процессов восприятия инноваций в национальной и региональных инновационных системах. 
Pезультаты: Выявлены экзогенные (тип экономической системы, открытость экономики, место в международном разделении труда) и эндогенные (конкуренция, институты, инновационный потенциал) факторы инновационного развития.

Экзогенные факторы напрямую не зависят от деятельности фирмы, а часто и всего государства, тем не менее динамика этих факторов должна быть учтена в процессе реализации и инновационной политики государства и инновационных проектов фирм. Более важными для предпринимателей являются эндогенные факторы. При этом необходимо учитывать, что основная часть потенциальных инновационных сдвигов создается в сфере генерации новых знаний, где человеческая деятельность определяется не технологической логикой производства, а законами и стимулами творческого процесса. В этой связи принципиальная особенность внутренних факторов инновационного развития заключается в том, что вводится новая переменная - интеллектуальный капитал, характеризующий объем накопленных научных знаний и практического опыта.

Детальная оценка факторов инновационной восприимчивости позволяет их классифицировать по месту возникновения в рамках существующего инновационного процесса: факторы окружения, бизнес-факторы, факторы правового регулирования, социальные факторы и факторы науки.

Bblвoдbl: Выявление факторов инновационной восприимчивости субъектов экономических отношений позволяет определить параметры инновационного взаимодействия инновационных компаний с внешними и внутренними элементами инновационного процесса.

Ключевые слова: инновационная восприимчивость, инновация, национальная инновационная система, инновационная активность, инновационная среда, внешние и внутренние факторы инновационного развития, инновационный потенциал, инновационный процесс.

\section{References}

Aguiar, L. European cooperative R\&D and firm performance: Evidence based on funding differences in key actions [Text] / L. Aguiar, P. Gagnepain // International Journal of Industrial Organization. — 2017. — Vol. 53. — P. 131. - Doi: 10.1016/j.ijindorg.2016.12.007.

Amoroso S. Sources of knowledge used by entrepreneurial firms in the European high-tech sector [Text] / S. Amoroso, D.B. Audretsch, A.N. Link // Eurasian Business Review. - 2018. - Vol. 8. — No. 1. — P. 55-70. DOI: $10.1007 / \mathrm{s} 40821-017-0078-4$.

Elnasri A. The contribution of research and innovation to productivity [Text] / A. Elnasri, K.J. Fox // Journal of Productivity Analysis. — 2017. — Vol. 47. — Special Issue No. 3. — P. 291-308. — DOI: 10.1007/s11123-017-05039.

Kurmanov N.A. Innovative activity of small and medium enterprises in Kazakhstan and their success factors [Text] / N.A. Kurmanov, D.A. Aibosynova // Herald of «Turan» University. — 2016. — Vol. 72(4). — P. $188-192$.

Marcotte C. Entrepreneurship and innovation in emerging economies [Text] / C. Marcotte // International Journal of Entrepreneurial Behavior \& Research. - 2014. - Vol. 20. — No. 1. - P. 42-65. — Doi: 10.1108/IJEBR-092012-0089.

Mukhtarova K. Problems of developing the foundations of sustainable competitiveness of industrial and innovative economy in Kazakhstan [Text] / K. Mukhtarova, S. Ziyadin, S. Kupeshova, R. Doszhan // Economic Annals-XXI. - 2017. — Vol. 168. - Is. 11-12. - P. 38-43. — DOI: 10.21003/ea.V168-08.

Shatrevich V. Industrialisation factors in post-industrial society [Text] / V. Shatrevich, V. Strautmane // Entrepreneurship and Sustainability Issues. — 2015. — Vol.3(2). — P. 157-172. — Doi: 10.9770/jesi.2015.3.2(4).

Tambovtsev V.L. On scientific validity of Russian science policy [Text] / V.L. Tambovtsev // Questions of Economy] — 2018. — Vol.: 70. - P.5-32. — Doi: 10.32609/0042-8736-2018-2-5-32.

Taubayev A.A. Formation in Kazakhstan institutional environment for the development of high-tech sector and innovative entrepreneurship [Text] / A.A. Taubayev, A.B. Kamenova, E.I. Borisova, Yu.M. Saifullina // Corporate Governance and Innovative Economic Development of the North. Bulletin of the Research Center of Corporate Law, Management and Venture Capital of Syktyvkar State University. — 2019. — No. 1. — P. 104-111. — DOI: 10.34130/2070-4992-2019-1-104-111.

Ulybyshev, D.N. Priority Directions of Cooperation and Interaction of the Countries of the Eurasian Economic Union in the Scientific and Innovative Environment [Text] / D.N. Ulybyshev, Ye. Petrenko, O. Lenkova, S. Akenov // Journal of Advanced Research in Law and Economics. — 2017. - Vol. 8. — Iss. 6(28). — P. 2024-2030. — DOI: $10.14505 /$ jarle.v8.6(28).40.

Vieira A. A Tale of Two Unions: Russia-Belarus Integration Experience and its Lessons for the Eurasian Economic Union [Text] / A. Vieira // Journal of Borderlands Studies. — 2017. — Vol. 32(1). — P. 41-53. — DOI: 10.1080/08865655.2016.1211959.

Владимирова О.Н. Управление инновационной восприимчивостью региона: методология и инструментарий [Текст]: автореф. дис. ... д-ра экон. наук / О.Н. Владимирова. — Красноярск: СГАУ, 2011. - 39 с.

Комков С.Ю. Механизмы экономического взаимодействия как фактор инновационной восприимчивости предприятий [Текст] / С.Ю. Комков // Вестн. Гомел. гос. техн. ун-та им. П.О. Сухого. — 2004. — № 1. C. $101-110$. 
Салимьянова И.Г. Методологические аспекты построения национальной инновационной системы: [Текст]: моногр. / И.Г. Салимьянова. - СПб.: СПбГИЭУ, 2011. - 224 с.

Улыбышев Д.Н. Возможности и механизмы развития казахстанского инновационного бизнеса в рамках Евразийского экономического союза [Текст] / Д.Н. Улыбышев, Н.Д. Кенжебеков // Экономика Центральной Азии. — 2017. — Т. 1. — № . 3. — C. 145-154. — DOI: 10.18334/asia.1.3.38490.

Шевченко М.Н. Оценка инновационной восприимчивости как фактор формирования стратегии инновационного развития аграрных предприятий [Текст] / М.Н. Шевченко, Е.С. Гончарук // ЭКОНОМИНФО. — 2018. — № 2. - C. 52-62. 